\begin{tabular}{|c} 
Ambiente \& Água - An Interdisciplinary Journal of Applied Science \\
ISSN 1980-993X - doi:10.4136/1980-993X \\
www.ambi-agua.net \\
E-mail: ambi.agua@gmail.com
\end{tabular}

\title{
Stability of an anaerobic single reactor filled with dolomitic limestone with increased organic load of sugarcane
}

\author{
doi:10.4136/ambi-agua.2112
}

Received: 12 Mar. 2017; Accepted: 04 Sep. 2017

\author{
Maria Magdalena Ribas Döll ${ }^{1 *}$; Larissa Beatriz de Sousa² \\ ${ }^{1}$ Universidade Estadual de Ponta Grossa (UEPG), Ponta Grossa, Paraná, Brasil \\ Campus Uvaranas, Departamento de Engenharia Civil. E-mail: maria.ribas@gmail.com \\ ${ }^{2}$ Universidade Estadual de Maringá (UEM), Maringá, Paraná, Brasil \\ Departamento de Engenharia Agrícola. E-mail: negalarissa@ yahoo.com.br \\ *Corresponding author
}

\begin{abstract}
The anaerobic single-stage reactor was evaluated to treat vinasse and to evaluate its stability. This bench reactor was filled with dolomitic limestone with a horizontal plug flow to simulate a drainage channel. The experiment lasted 129 days while the reactor was submitted to different applied organic concentrations (chronologically applied: $3.0 ; 5.0 ; 12.0 ; 9.0$ and $7.5 \mathrm{~g} \mathrm{~L}^{-1}$ as COD, chemical oxygen demand). COD removals were 50\% and $9 \%$ with 3.0 and $7.5 \mathrm{~g} \mathrm{~L}^{-1}$, respectively. With $12.0 \mathrm{~g} \mathrm{~L}^{-1}$, reactor efficiency increased to $33 \%$, with an abrupt drop to $3 \%$ on the $84^{\text {th }}$ day. Therefore, in order to avoid reactor collapse, a remedial measure was necessary. The system remained in batch without feeding for 19 days (from the $85^{\text {th }}$ to the $104^{\text {th }}$ day) with $9.0 \mathrm{~g} \mathrm{~L}^{-1}$. Afterwards, it was observed that the performance of the system tended to stabilize, reaching $47 \%$ with $7.5 \mathrm{~g} \mathrm{~L}^{-1}$ in the $118^{\text {th }}$ day. At the end of the experiment, the potassium content of the wastewater decreased from $800 \mathrm{mg} \mathrm{L}^{-1}$ to $594 \mathrm{mg} \mathrm{L}^{-1}$ (on an average $25 \%$ ) and calcium and magnesium increased within the reactor liquor. The dissolution of the limestone inside the liquor reactor probably caused this result. After the treatment with limestone, the average $\mathrm{pH}$ value of the effluent increased from 4.9 to over 6.0 in all organic concentrations. It could be concluded that the reactor filled with dolomitic limestone in these operational conditions assured a low efficiency in COD removal, potassium reduction, increasing values of $\mathrm{pH}$, alkalinity, calcium and magnesium. The instability was observed when there was increase in organic load to $12 \mathrm{~g} \mathrm{~L}^{-1}$ with subsequent recovery.
\end{abstract}

Keywords: ethanol distillery, agro-industrial wastewater, biological load, vinasse, anaerobic treatment.

\section{Estabilidade de um reator anaeróbio de único estágio preenchido com pedras de calcário dolomítico com aumento da carga orgânica de vinhaça de cana de açúcar}

\section{RESUMO}

O reator anaeróbico de estágio único foi avaliado para tratar a vinhaça e avaliar sua estabilidade. Este reator de bancada foi preenchido com calcário dolomítico com fluxo contínuo horizontal simulando um canal de drenagem da vinhaça. O experimento durou 129 dias em que o reator foi submetido a diferentes concentrações orgânicas cronologicamente aplicadas $(3,0$; 
5,0; 12,0; 9,0 e 7,5 $\mathrm{g} \mathrm{L}^{-1}$ como DQO, demanda química de oxigênio). As remoções de DQO foram de $50 \%$ e $9 \%$ com 3,0 e 7,5 $\mathrm{g} \mathrm{L}^{-1}$, respectivamente. Com $12,0 \mathrm{~g} \mathrm{~L}^{-1}$ a eficiência do reator aumentou para 33\%. Mas, houve uma queda abrupta para $3 \%$ aos 84 dias. Então, a fim de evitar o colapso do reator, uma medida corretiva foi necessária. $\mathrm{O}$ sistema permaneceu em regime batelada sem alimentação durante 19 dias (do $85^{\circ}$ ao $104^{\circ}$ dia) com 9,0 g de $\mathrm{L}^{-1}$. Depois, observou-se que o desempenho do sistema tendeu à estabilidade, atingindo $47 \%$ com $7,5 \mathrm{~g} \mathrm{~L}^{-1}$ no $118^{\circ}$ dia. No final do experimento, o teor de potássio do efluente diminuiu de $800 \mathrm{mg} \mathrm{L}^{-1}$ para $594 \mathrm{mg} \mathrm{L}^{-1}$ (em média 25\%) e cálcio e magnésio aumentaram dentro do licor do reator. Provavelmente, isto pôde ser observado devido a dissolução do calcário dentro do reator. Após o sistema de tratamento com calcário, o valor médio do $\mathrm{pH}$ do efluente aumentou de 4,9 para mais de 6,0 em todas as concentrações orgânicas. Pôde-se concluir que o reator preenchido com rochas de calcário dolomítico nestas condições operacionais assegurou baixa eficiência na remoção de DQO, redução de potássio, valores crescentes de $\mathrm{pH}$, alcalinidade, cálcio e magnésio. A instabilidade foi observada quando houve os aumentos da carga orgânica para $12 \mathrm{~g} \mathrm{~L}^{-1}$ com recuperação subsequente.

Palavras-chave: carga biológica, destilaria de etanol, efluente agroindustrial, vinhaça, tratamento anaeróbio.

\section{INTRODUCTION}

Brazilian production for the harvest year 2015/2016 was $30.562 .284 \mathrm{~m}^{3}$ of ethanol according to Ministry of Agriculture, Livestock and Food Supply (Brazil, 2017), and Brazil has 383 ethanol distilleries in operation (ANP, 2016).

Vinasse is the final by-product of biomass distillation of sugar crops (beet and sugarcane), starch crops (corn, wheat, rice, and cassava), or cellulosic material (harvesting crop residues, sugarcane bagasse, and wood), mainly for the production of ethanol (Christofoletti et al., 2013). The wastewater is generated at a high temperature $\left(90^{\circ} \mathrm{C}\right.$ ) (Wilkie et al., 2000), and in many plants it is held in a tank until it reaches ambient temperature before it is used in soil.

The volume of vinasse wastewater generated depends on the production of alcohol. The final disposition of the vinasse presents a business and environmental challenge, as it generated in great volume, about 12 to 14 liters for each liter of ethanol produced (Wilkie et al., 2000). Due to the large quantities of vinasse produced, alternative treatments and uses have been developed, such as recycling of vinasse in fermentation, fertirrigation, concentration by evaporation, and yeast and energy production (Christofoletti et al., 2013).

In order to optimize the energy potential and sustainability of bioethanol production, the liquid streams should not be considered as residues of the process (Moraes et al., 2015). Also, the effluent contains significant amounts of nutrients and organic matter because the vinasse is a liquid byproduct of the distillation of the fermented broth of the sugarcane. It is rich in potassium, calcium, magnesium, sulfur and micronutrients (Guagnoni et al., 2003). Ribas (2006) observed that the potassium content of vinasse was wide-ranging, from 1.7 to $12.5 \mathrm{~g} \mathrm{~L}^{-1}$. The same was observed by Moraes et al. (2015) in a wide review of literature, and the content ranges from 0.6 to $6.5 \mathrm{~g} \mathrm{~L}^{-1}$ with different feedstocks of sugarcane.

The most widely used alternative is the application of this liquid to cultivated soils with sugarcane as biofertilizer. However, the successive application of the residue in the same cultivation areas has resulted in alterations in soil and groundwater quality. Brazilian Resolution CONAMA n. 357 (CONAMA, 2005) establishes dispersement patterns that may only be used after some type of treatment.

In this context, anaerobic digestion is becoming a great environmental and economic asset for generating methane and for being marketed as carbon credits or as an energy resource. Anaerobic treatment reduces the organic matter, but even the minerals can be concentrated. 
Vinasse is considered a highly saline organic residue, containing approximately $75 \%$ biodegradable material and $20 \%$ mineral salts, with $8 \%$ potassium (Wilkie et al., 2000). It is assumed that its repeated disposition in all types of soils can create an imbalance among the soil bases (Bataglia et al., 1986; Silva et al., 2007), with adverse effects on agricultural soils and biota in general (Christofoletti et al., 2013). In the proposed system, the use of limestone rocks in the anaerobic reactor provides slow solubilization of calcium to the wastewater in treatment, and can lead to more-balanced levels between calcium and potassium.

The integration of anaerobic digestion in a sugarcane bio-refinery to treat and recover the energy or organic matter contained in the vinasse can be a great alternative (Wilkie et al., 2000; Tonello and Ribas, 2009; Moraes et al., 2015).

Anaerobic digestion consists of complex and sequential metabolic processes that occur in the absence of molecular oxygen and depend on the activity of at least three distinct groups of microorganisms (acidogenic bacteria, acetogenic bacteria and methanogenic archaea) to promote the stable and self-regulating fermentation of organic matter, resulting mainly in methane and carbon dioxide gases (Mosey, 1982). Each group has distinct optimum growth conditions for the development of the global process when there is stability inside the reactor.

The stability of an anaerobic reactor depends on several parameters; for example $\mathrm{pH}$, alkalinity and concentration of organic acids, etc (Pohland and Ghosh, 1971; Speece, 1996). However, all microorganism groups involved in anaerobic digestion can develop in different lengths of a single reactor.

Several configurations of anaerobic reactors have been used in the anaerobic digestion of vinasse. The anaerobic reactor plug flow has been used widely in the treatment of several types of wastewater with good performance and satisfactory reduction of organic load (Ribas and Barana, 2003). In this reactor configuration, material supports for the microorganisms should be used.

Due to its advantages (low cost, non-toxic, non-reactive with carbon dioxide to generate vacuum inside the reactor, contains macronutrients that will enrich the biofertilizer) compared to other alkalizing substances, dolomitic limestone has been used as an anaerobic reactor filling to neutralize generated acids in the process. In Brazil, research with dolomitic limestone as material support was initiated in an acidic reactor for the cassava wastewater treatment (Ribas and Cereda, 2003) and later for sugarcane vinasse (Tonello and Ribas, 2009).

Regarding phase separation, anaerobic digestion can occur in a single reactor or with phase separation, i.e., uncoupling acidogenesis from methanogenesis.

The up-flow sludge blanket reactor (UASB) is the most-used configuration for vinasse anaerobic treatment due its better performance (Wiegant et al., 1986, Souza et al., 1992, Vlissidis and Zouboulis, 1993, Driessen et al., 1994 and Harada et al., 1996). However, other configurations of bench scale reactors have already been studied as alternatives to vinasse treatment: fluidized reactor filled with pumice stone (Balaguer et al., 1997) or with activated granular carbon (Fdz-Fernandez et al. 2001), structured-bed reactor (Aquino et al., 2017) and horizontal anaerobic fixed-bed reactor with single stage (Telh, 2001) and two stages (Tonello and Ribas, 2009).

A similar configuration of the reactor to the present work was used for vinasse treatment in anaerobic reactors of two phases (Tonello and Ribas, 2009). However, in this study the reactor was singlestage filled with limestone. This configuration works as a reactor plug flow that is a simplified digester built with cheap materials and simpler operation than other systems that require agitation (Kubiac and Dubuis, 1985).

Limestone rocks have already been used for alkaline support of reactors of various sizes. Silva et al. (2012) evaluated mine water treatment with limestone for sulfate removal with particle sizes between $0.42 \mathrm{~mm}$ and $0.59 \mathrm{~mm}$ as fixed-bed experiments. Zhou et al. (2011) used 
an average diameter of 3-15 mm of sulfur-limestone as media in a lab-scale upflow biofilter. Tonello and Ribas (2009) filled the reactor with limestone sizes between $19 \mathrm{~mm}$ and $38 \mathrm{~mm}$. Ribas and Cereda (2003) assessed two sizes of dolomitic limestone to stabilize cassava wastewater during the acidogenic phase in anaerobic reactor, one of $7.93 \mathrm{~mm}-25.4 \mathrm{~mm}$ and the other of $25.4 \mathrm{~mm} 38.1 \mathrm{~mm}$. As can be observed, the size of the material used as a fixed bed for anaerobic reactors is highly variable.

Anaerobic reactors presented stability and good performance, with COD removal of $64 \%$ in the highest volumetric organic load applied, $3.3 \mathrm{~g} \mathrm{~L}^{-1} \mathrm{~d}^{-1}$. The $\mathrm{pH}, \mathrm{AI} / \mathrm{AP}$ ratio, bicarbonate alkalinity and total volatile acids also had optimum results of 7.8, 0.9, $0.63 \mathrm{gHCO}_{3}^{-} \mathrm{L}^{-1}$ and $1.42 \mathrm{gHAc} \mathrm{L}^{-1}$, respectively. The highest biogas production was on average $1.4 \mathrm{~L} \mathrm{~d}^{-1}$ with a yield of $0.112 \mathrm{~L}_{\text {biogas. }} \mathrm{L}_{\text {reactor. }} \mathrm{d}^{-1}$ and $0.271 \mathrm{~L}$.biogas.gDQO ${ }_{\text {rem. }} \mathrm{d}^{-1}$ (Tonello and Ribas, 2009).

Therefore, the objective of the present study was to evaluate the stability of a horizontal anaerobic single reactor with increased organic load, filled with dolomitic limestone rocks, the with goals of organic matter removal, conversion from organic matter to biogas and the alteration of the chemical characteristics of the vinasse regarding the levels of calcium, magnesium and potassium.

\section{MATERIALS AND METHODS}

\subsection{Wastewater}

The wastewater used was collected in the vinasse storage tank and stored at $4^{\circ} \mathrm{C}$. The characteristics of the vinasse used in the experiment were: $\mathrm{pH} 4.78$, total solids $16617 \mathrm{mg} \mathrm{L}^{-1}$, biological oxygen demand $3430 \mathrm{mg} \mathrm{L}^{-1}$, chemical oxygen demand $28217 \mathrm{mg} \mathrm{L}^{-1}$, calcium hardness $2000 \mathrm{mg} \mathrm{Ca} \mathrm{L}{ }^{-1}$, magnesium hardness $1680 \mathrm{mg} \mathrm{Mg} \mathrm{L}^{-1}$, electric conductivity $10050 \mu \mathrm{S} \mathrm{cm}^{-1}$, total nitrogen $560 \mathrm{mg} \mathrm{L}^{-1}$, nitrate $\left(\mathrm{NO}_{3}{ }^{-}\right) 45.00 \mathrm{mg} \mathrm{L}^{-1}$, nitrite $\left(\mathrm{NO}_{2}{ }^{-}\right) 2.00 \mathrm{mg}$ $\mathrm{L}^{-1}$, potassium $440.0 \mathrm{mg} \mathrm{L}^{-1}$ and sulfate $\left(\mathrm{SO}_{4}{ }^{2-}\right) 250.0 \mathrm{mg} \mathrm{L}^{-1}$.

\subsection{Anaerobic single reactor}

The system was comprised of a tube of PVC (polyvinyl chloride) 1.0 meter in length and $0.1 \mathrm{~m}$ in diameter, with a total volume of $6.0 \mathrm{~L}, 50 \%$ filled with limestone rocks $(\mathrm{p} / \mathrm{v})$ with a useful volume of $3.0 \mathrm{~L}$.

The reactor was arranged horizontally simulating the normal piping conduction of vinasse to the field, as shown in the Figure 1.

The system was fed daily, and the effluent was fed to the reactor by gravity. The feeding container was located one meter above the reactor, suspended by a wooden support. The affluent was put in the upper container, which was connected to the $19 \mathrm{~mm}$-pipe to feed the reactor. In the superior part of the reactor, three transparent $10 \mathrm{~mm}$ plastic tubes were coupled with the external tips immersed in water, where the biogas escaped. The reactor was operated at room temperature. The inflow $\mathrm{pH}$ was not corrected in order to verify the dolomitic limestone action in the buffering and system operation. 


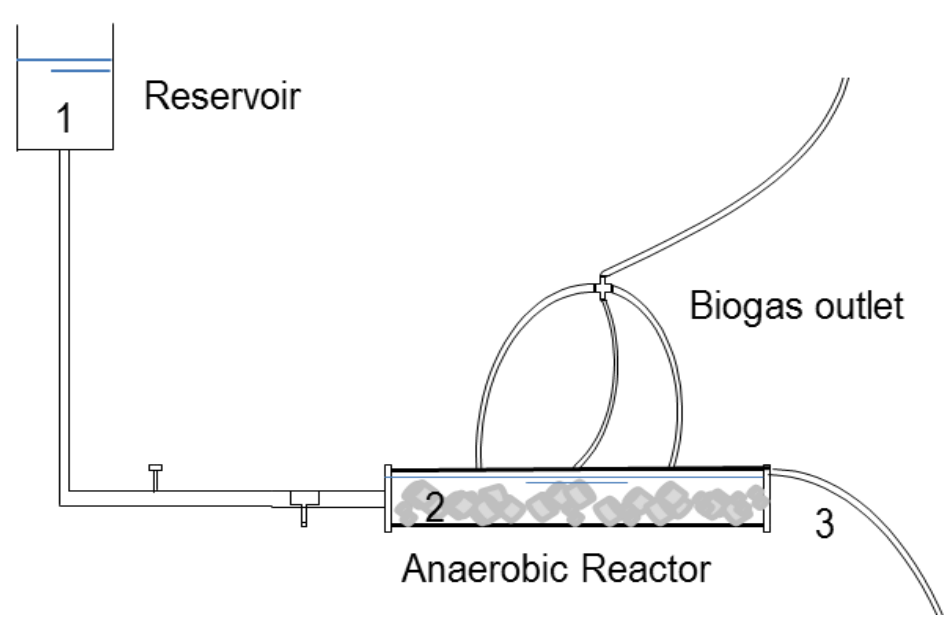

Figure 1. Schematic diagram of the experimental apparatus: 1 - elevated inflow reservoir; 2 - limestone rocks packed inside the reactor; 3 - treated effluent outlet.

\subsection{Experiment}

The $\mathrm{pH}$ of the affluent was measured daily and was not corrected. The flow of the reactor was adjusted to be on average $2.52 \mathrm{~L} \mathrm{~d}^{-1}$ to maintain the HRT (hydraulic retention time) close to 1.0 day. The variation of the organic load over time was arranged with the vinasse diluted in water to concentrations of $3.0 ; 5.0 ; 12.0 ; 9.0$ and $7.5 \mathrm{~g} \mathrm{COD} \mathrm{L}^{-1}$. The goal was to adapt the inoculum and detected reactor instability to the highest organic concentration using a concentration of up to $10.0 \mathrm{~g} \mathrm{COD} \mathrm{L}^{-1}$ as a reference applied in a two-phase reactor (Tonello and Ribas, 2009). Between 9.0 and $7.5 \mathrm{~g} \mathrm{COD} \mathrm{L}^{-1}$, the system stayed in batch without feeding for 19 days (from the $90^{\text {th }}$ to the $108^{\text {th }}$ day) with an influent of $9.0 \mathrm{~g} \mathrm{COD} / \mathrm{L}$ to restore reactor performance and acid consumption (Pohland and Ghosh, 1971). Table 1 presents the operation parameters.

Table 1. Experimental conditions submitted to the anaerobic reactor in each experimental phase.

\begin{tabular}{llllll}
\hline \multirow{2}{*}{ Conditions } & \multicolumn{5}{c}{ Organic concentration $\left(\mathrm{g} \mathrm{COD} \mathrm{L}^{-1}\right)$} \\
\cline { 2 - 6 } & 3.0 & 5.0 & 12.0 & 9.0 & 7.5 \\
\hline Q $_{\text {in }}\left(\mathrm{L} \mathrm{d}^{-1}\right)$ & 2.96 & 2.67 & 2.47 & 2.48 & 2.25 \\
OT $(\mathrm{d})$ & 17 & 18 & 43 & 11 & 21 \\
Period $(\mathrm{d})$ & $1-17$ & $18-35$ & $36-78$ & $79-89$ & $109-129$ \\
HRT $(\mathrm{d})$ & 1.00 & 1.02 & 0.93 & 1.05 & 1.00 \\
OLR $\left(\mathrm{g} \mathrm{L}^{-1} \mathrm{~d}^{-1}\right)$ & 3.0 & 4.9 & 12.9 & 8.6 & 7.5 \\
VOL $\left(\mathrm{g} \mathrm{L}^{-1} \mathrm{~d}^{-1}\right)$ & 2.96 & 4.45 & 9.88 & 7.44 & 5.62 \\
\hline
\end{tabular}

$\mathrm{Q}_{\text {in }}$ - inflow rate; OT - operation time; HRT hydraulic retention time; OLR-organic loading rate; VOL - volumetric organic loading.

Organic loading rate (OLR) was calculated by (Equation 1):

$O R L\left(g_{C O D} L^{-1} d^{-1}\right)=\frac{C_{C O D}}{H D T}$

In which $C_{C O D}$ is the COD concentration $\left(\mathrm{g} \mathrm{L}^{-1}\right)$ in the affluent and HDT is the hydraulic retention time (days). And the volumetric organic loading rate was calculated by (Equation 2):

$\operatorname{VOL}\left(g_{\text {COD }} L_{\text {reactor }}^{-1} d^{-1}\right)=\frac{Q_{\text {in }} \times C_{C O D}}{V_{\text {reactor }}}$ 
In which $Q_{\text {in }}$ is the inflow rate $\left(\mathrm{L} \mathrm{d}^{-1}\right)$ and $V_{\text {reactor }}$ is the useful volume (L).

The experiment lasted for 129 days, including the period without feeding after the fourth phase.

\subsection{Inoculum}

The inoculum originated from an anaerobic batch reactor that treated swine manure for 30 days and was introduced to the effluent in the fifth day of operation. The inoculum was composed of $7.4 \mathrm{~g}$ TS/Lsludge, $5.5 \mathrm{~g}$ TS/ $\mathrm{L}_{\text {sludge }}$ and $1.9 \mathrm{~g} \mathrm{TS} / \mathrm{L}_{\text {sludge. }}$

\subsection{Limestone Rocks}

The reactor was filled with dolomitic limestone previously selected to be sized between 4.75 and $9.52 \mathrm{~mm}$ in mesh sieve ABNT (in English, Brazilian Association of Technical Standards) 4 and $3 / 8$ ", respectively. That is the commonly used grading size of commercial coarse aggregate (ASTM C 33, 2016); in Brazil the size is equivalent to grade zero, since the literature presents a wide range of sizes, as already discussed briefly. The limestone used was $30 \%$ calcium oxide and $20 \%$ magnesium oxide.

\subsection{Analytical methodology}

The monitoring of the adaptation phase of the reactor was accompanied by the analyses of pH (APHA, 2012), alkalinity to bicarbonate (partial), intermediary and total, total volatile acidity (Dillalo and Albertson, 1961; Ripley et al., 1986) and chemical demand of oxygen (APHA, 2012). The levels of solids (APHA, 2012) were determined in the inoculum used.

\section{RESULTS AND DISCUSSION}

The effluent entered without $\mathrm{pH}$ correction, averaging 4.84. Daily, the $\mathrm{pH}$-treated effluent was measured an increase in $\mathrm{pH}$ of between 5.5 and 7.0 occurred naturally made by the action of calcareous in contact with the wastewater.

In general, the analyses to monitor the performance of the anaerobic system presented satisfactory results for the adaptation phase of the system. The average values of the effluent $\mathrm{pH}$ in the study of load variation were above 6.0, which is inside of the acceptable range of 6.0 to 7.4 (Speece, 1996). Only the last organic load $\left(7.5 \mathrm{~g} \mathrm{~L}^{-1}\right)$, had treated effluent that was characterized with high acidity.

Notice that the limestone rocks not just had great importance in the system for supplying carbonates for the elevation of the $\mathrm{pH}$ (Figure 2), but it was also important to supply a physical fixed bed for the microorganisms. Studies show that part of the bacteria lives loose inside the reactor and the other part needs a base to which it can adhere (Speece, 1996).

Regarding $\mathrm{pH}$, limestone use in the reactor will cause a rise in $\mathrm{pH}$ with the removal of the $\mathrm{H}^{+}$ions, alkalinity and hardness as $\mathrm{H}^{+}$and $\mathrm{CO}_{2}$ react away to form calcium bicarbonate as in the stoichiometry below, for example (Watten et al., 2017):

$$
\begin{aligned}
& \mathrm{CaCO}_{3}+\mathrm{H}^{+} \leftrightarrow \mathrm{HCO}_{3}^{-}+\mathrm{Ca}^{2+} \\
& \mathrm{HCO}_{3}{ }^{-}+\mathrm{H}^{+} \leftrightarrow \mathrm{H}_{2} \mathrm{CO}_{3} \leftrightarrow \mathrm{H}_{2} \mathrm{O}+\mathrm{CO}_{2} \\
& \mathrm{CaCO}_{3}+\mathrm{H}_{2} \mathrm{CO}_{3} \leftrightarrow \mathrm{Ca}^{2+}+2 \mathrm{HCO}_{3}^{-} \\
& \mathrm{CaCO}_{3}+\mathrm{H}_{2} \mathrm{O} \leftrightarrow \mathrm{Ca}^{2+}+\mathrm{HCO}_{3}^{-}+\mathrm{OH}^{-}
\end{aligned}
$$

In the COD concentration of $3.0 \mathrm{~g} \mathrm{~L}^{-1}$, the effluent $\mathrm{pH}$ was in the range of 4.3 to 5.22 , and after being treated in the system, the effluent $\mathrm{pH}$ ranged between 6.33 and 7.31. According to Speece (1986), for the methanogens archaea the $\mathrm{pH}$ should be between 6.8 and 7.4. Around 7.2, the $\mathrm{pH}$ is considered slightly alkaline. 
In the startup of the reactor with $3.0 \mathrm{~g} \mathrm{~L}^{-1}$, the values of the effluent $\mathrm{pH}$ crossed the value of 7.0, reaching 7.31, but with the increase of the organic load to $5.0 \mathrm{~g} \mathrm{~L}^{-1}$ the $\mathrm{pH}$ values oscillated between 5.55 and 7.27.

As soon as the load was increased to $5.0 \mathrm{~g} \mathrm{COD} \mathrm{L}^{-1}$, the system presented a small drop in the $\mathrm{pH}$ value of 6.5. The same behavior was observed with the $12.0 \mathrm{~g} \mathrm{COD} \mathrm{L}^{-1}$, when the $\mathrm{pH}$ had a wide oscillation; more time therefore was required in order to stabilize the reactor, with 43 days in the same concentration. The $\mathrm{pH}$ average in this phase was 6.14. Since vinasse does not have a high protein content, as can be inferred from the work of Wilkie et al. (2002), Moraes et al. (2015), Ferraz Junior et al. (2016), Aquino et al. (2017), it has a low-buffer capacity that causes slow system recovery and unstable conditions for microorganisms.

The ability to avoid large variations in $\mathrm{pH}$ and to neutralize acids is called alkalinity. In anaerobic digestion, this property naturally originates with the methanogenesis and decomposition of proteins and other substrates (Silva and Boncz, 2012).

A smaller load still was therefore applied, $9.0 \mathrm{~g} \mathrm{COD} \mathrm{L}^{-1}$, in order to recover the system, because the reactor was presenting a high concentration of volatile acids $\left(1923 \mathrm{mg} \mathrm{L}^{-1}\right.$ on average) with $12.0 \mathrm{~g} \mathrm{COD} \mathrm{L}^{-1}$. Therefore, after this phase, the system remained in batch without feeding for 19 days, so that the methanogenic archaeas had time to consume the produced organic acid. Afterwards, the organic concentration was decreased to $7.5 \mathrm{~g} \mathrm{COD} \mathrm{L}^{-1}$.

It is noticed that after the period in batch, between 9.0 and $7.5 \mathrm{~g} \mathrm{COD} \mathrm{L}^{-1}$, corresponding to 19 days without feeding interruption (as shown in the graph, Figures 2 and 3), there was the expected recovery with an increase of the effluent $\mathrm{pH}$ up to 7.0.

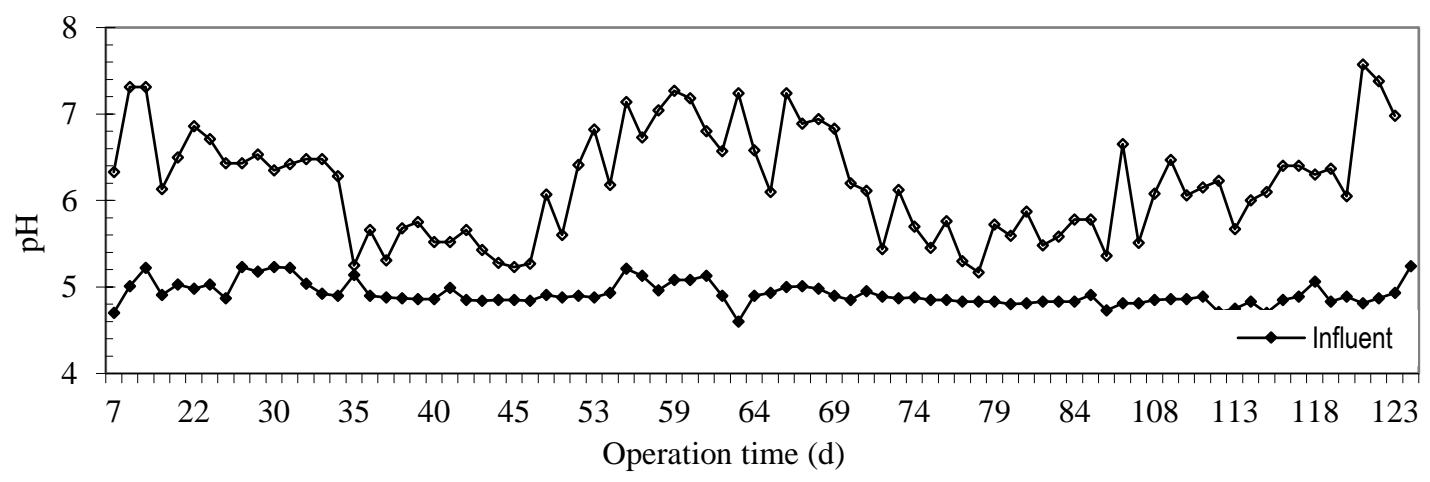

Figure 2. Values of $\mathrm{pH}$ of the effluent and influent measured during all of the experimental phases.

Regarding COD, it was observed that the reactor in the concentration of $3.0 \mathrm{~g} \mathrm{COD} \mathrm{L}^{-1}$ presented a $50 \%$ removal of COD, according to the graph in Figure 3.

The $\mathrm{pH}$ stability (on average $\mathrm{pH} 7.0$ ) began with $5.0 \mathrm{~g} \mathrm{COD} \mathrm{L}^{-1}$ of organic load. However, it was observed that the efficiency dropped to $9 \%$ of COD removal with 21 days of operation.

In the graph of Figure 3, great variations in the removal according to the increase of organic load and no removal were observed. The variations can be observed by the standard deviation with respect to the average COD in each applied load.

The non-removal was observed in the third phase, with a concentration of $12.0 \mathrm{~g} \mathrm{COD} \mathrm{L}^{-1}$, which might have been caused by a great increase of organic load from flies of the order Diptera, more specifically of the Calliphoridae family, suddenly appearing inside the system. The system was cleaned and a screen was placed on the reservoir and the non-removal did not reoccur.

An increase the retention time with the applied organic load of $12.0 \mathrm{~g} \mathrm{COD} \mathrm{L}^{-1}$ was necessary in this stage so that there was time for a higher removal. The system tended to obtain a reduction of $33 \%$ in the same phase of the experiment, until the $77^{\text {th }}$ day. 


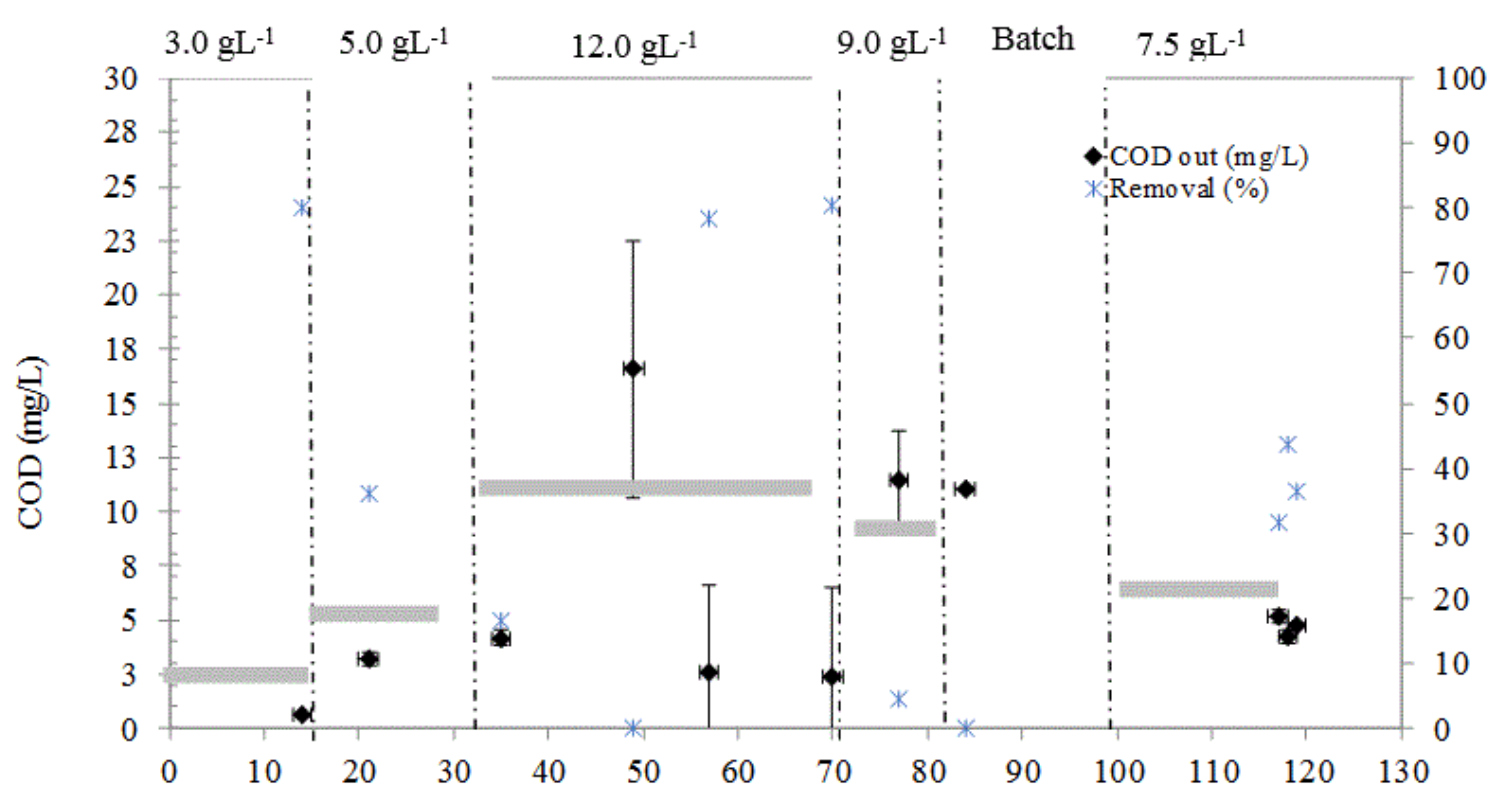

Operation time (d)

Figure 3. Monitoring and removal of COD during all of the organic loadings. Note: Horizontal bars delimit the applied load.

As the organic load increased in the system, COD removal slightly decreased, probably due to the organic "shock" suffered by the microorganisms causing yield reduction.

After the feeding interruption period in batch of the system for 19 days, between the $79^{\text {th }}$ and $89^{\text {th }}$ day, the reactor gradually presented recovery reaching $47 \%$ of removal with $7.5 \mathrm{~g} \mathrm{COD} \mathrm{L}^{-1}$.

The bicarbonate alkalinity showed in Figure 4 is a parameter used to indirectly evaluate the performance of anaerobic systems. It was observed with 3.0 and $5.0 \mathrm{~g} \mathrm{COD} \mathrm{L}^{-1}$, the system presented alkalinity production to bicarbonate.

In $12.0 \mathrm{~g} \mathrm{COD} \mathrm{L}^{-1}$, an accentuated drop in alkalinity and an increase of the total volatile acidity was measured, probably due to high applied organic load which stopped the operation of the methanogen microorganisms that are known be sensitive to abrupt changes of affluent concentration. But the system recovered after the $49^{\text {th }}$ day in the same organic concentration, again generating bicarbonate alkalinity of approximately $1500 \mathrm{mgCaCO}_{3} \mathrm{~L}^{-1}$. From this point on, the system presented variations in the values of the effluent.

Viana (2006) studied the thermophilic treatment (at $55^{\circ} \mathrm{C}$ ) of cane vinasse by an UASB reactor with progressive increase of organic load. The operation reached the organic limit loading in $6.5 \mathrm{~g} \mathrm{COD} \mathrm{L}^{-1} \mathrm{~d}^{-1}$ ( 1 day of hydraulic detention), limited by the excessive production of total volatile acids beyond $1200 \mathrm{mg} \mathrm{L}^{-1}$, too toxic a methanogen biomass.

Tonello and Ribas (2009) operated under environmental conditions and a reactor model similar to this work. When the methanogen reactor was submitted to $10.0 \mathrm{~g} \mathrm{COD} \mathrm{L}^{-1}$ of cane vinasse, the COD removal was $64 \%$ and $\mathrm{pH} 7.8$.

The instability of the anaerobic digestion process happens when the speed of volatile acids production is larger than its consumption, which can result in the fall of the $\mathrm{pH}$ and in the inhibition of the methanogenic archaeas activity. Thus, the alkalinity measures, mainly the bicarbonate alkalinity and volatile acids salts, supply fundamental data for the monitoring of anaerobic systems (Foresti, 1994). 
Figure 4 shows the behavior of the bicarbonate alkalinity (BA) along every experimental phase with duration of 124 days. It is observed that the affluent presented insignificant amounts of BA, because no alkalizing agent was added and the vinasse has low buffer capacity.

It can be inferred that the higher amount of BA in the effluent indicates greater stability in the anaerobic system on the part of the methanogenic microorganisms, since bicarbonate is a product of the methanogenic metabolism.

In Figure 4 it is possible to observe that total volatile acidity (TVA) was produced during of the experimental phases in the effluent, which demonstrates that the acidogenic phase that is the precursory phase of methane production occurred satisfactorily. This could have harmed the methanogenic stage, because in high concentrations of acidity, methanogenic archaeas cannot degrade organic acids and convert to methane, because it does not consume the substrate as quickly.

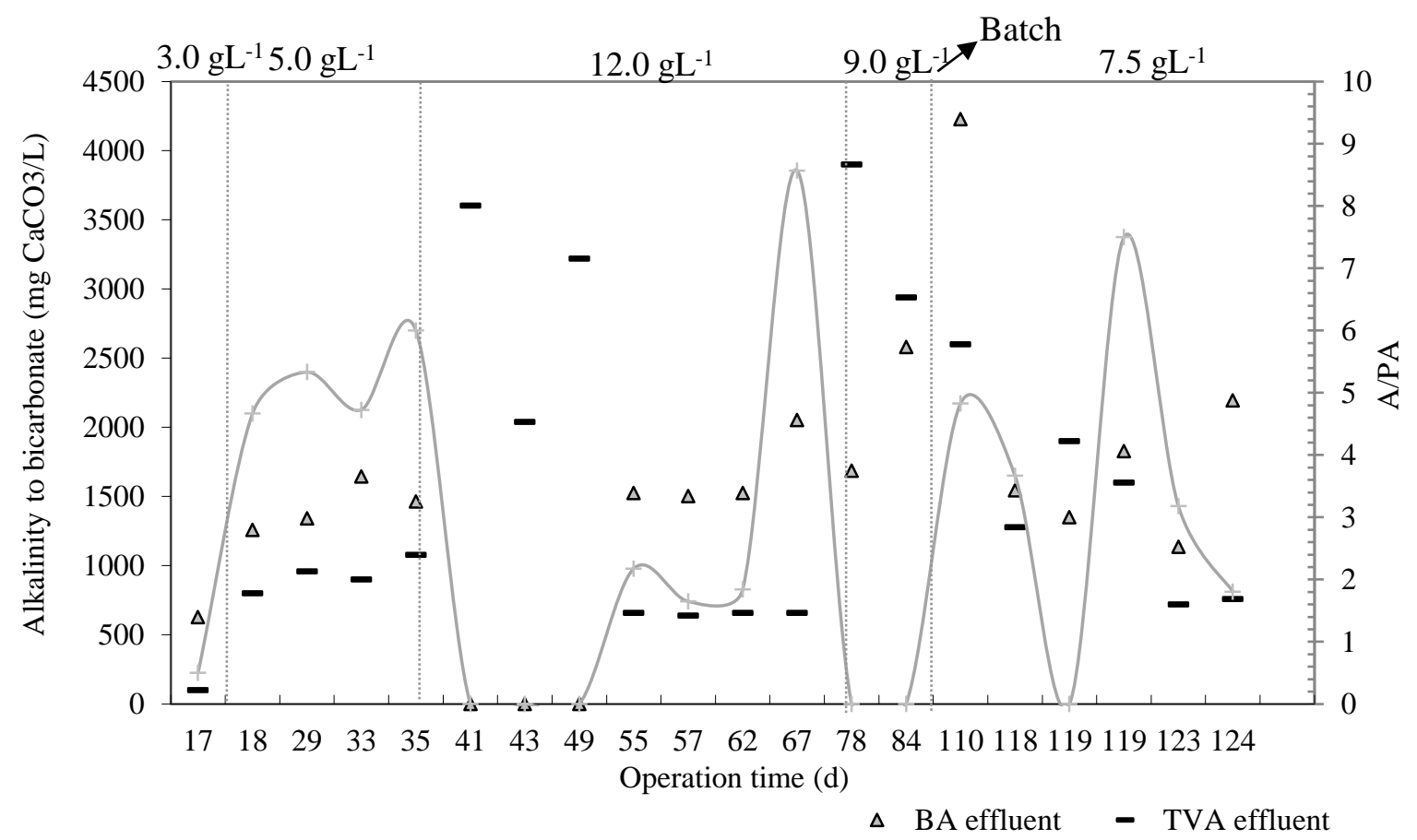

Figure 4. Bicarbonate alkalinity and total volatile acidity of the effluent.

The ratio between intermediate alkalinity (IA) and partial alkalinity (PA) presented represents a balance between intermediary alkalinity (corresponding to bicarbonate) and partial alkalinity (corresponding to organic acids) that is measured in the output of the anaerobic reactor.

Tonello and Ribas (2009) observed average values with the organic load of $10.0 \mathrm{~g} \mathrm{COD} \mathrm{L}^{-1}$ an IA/PA ratio of 0.9 , bicarbonate alkalinity of $0.63 \mathrm{gHCO}_{3} \mathrm{~L}^{-1}$ and total volatile acidity of $1.42 \mathrm{~g}$ acetic acid. $\mathrm{L}^{-1}$.

Some authors, as in the well known scientific paper of Ripley et al. (1986), consider that this relationship should be close to 0.3 to indicate the stability of the system. In this case, the relationship IA/PA varied during the whole experimental phase from 0 to 8.5 , indicating the instability of the adaptation phase in all organic loads evaluated.

Among the elements calcium, magnesium and potassium, interesting results were observed, considering the treated effluent as bio fertilizer, because one of the limitations of the soils in the humid tropical area is the low fertility in depth. This fact is reflected in the small volume explored by the sugar cane root and, consequently, lower productivity. 
Table 2 displays the values of the analyzed elements of four removed samplings of the last experimental phase and the relationship between $\mathrm{K}: \mathrm{Ca}: \mathrm{Mg}$ of both influent and effluent.

It was observed that the relationship among the elements $\mathrm{Mg}: \mathrm{Ca}: \mathrm{K}$, calculated by dividing the largest values for the smallest among them $(\mathrm{Mg})$, decreased. The $\mathrm{Mg}$ values in the effluent decreased due an increase of the $\mathrm{Ca}$ and $\mathrm{Mg}$ from the dolomitic limestone. In spite of the amount that those two elements increased, there was no variation in the relationship between the effluent and influent, except in the sampling of the $119^{\text {th }}$ day.

The treated effluent can be used as biofertilizer with larger the element amounts and morebalanced levels among them, which are better for soil fertility and for nutrient absorption by the sugar cane crop. Notice in Table 2 that $\mathrm{Ca}$ and $\mathrm{Mg}$ increased in the effluent and that $\mathrm{K}$ decreased in all of the samples with regard to the effluent, which possibly characterizes a biofertilizer of better quality. But to prove such hypothesis, it would be necessary to test its application in soil to observe the effects on the crop.

Table 2. Analyses of calcium, potassium and magnesium when the reactor was submitted to the organic load of $7.5 \mathrm{~g} \mathrm{COD} \mathrm{L}^{-1}$ of both influent and effluent.

\begin{tabular}{ccccccccc}
\hline \multirow{2}{*}{\begin{tabular}{c} 
Collection $\begin{array}{c}\text { Influent } \\
\text { Day }\end{array}$ \\
\cline { 2 - 9 }
\end{tabular}} & $\mathrm{Ca}$ & $\mathrm{Mg}$ & $\mathrm{K}$ & $\mathrm{Mg}: \mathrm{Ca}: \mathrm{K}$ & $\mathrm{Ca}$ & $\mathrm{Mg}$ & $\mathrm{K}$ & $\mathrm{Mg}: \mathrm{Ca}: \mathrm{K}$ \\
& & $\mathrm{mg} \mathrm{L} \mathrm{m} \mathrm{L}^{-1}$ & & & & & \\
\hline 116 & 166.04 & 72.96 & 792 & $1: 2: 10$ & 314.92 & 178.36 & 528 & $1: 2: 3$ \\
117 & 166.04 & 72.96 & 792 & $1: 2: 10$ & 274.52 & 155.66 & 409,2 & $1: 2: 3$ \\
118 & 204.53 & 107.49 & 924 & $1: 2: 9$ & 380.47 & 197.13 & 858 & $1: 2: 4$ \\
119 & 141.20 & 52.66 & 686 & $1: 3: 13$ & 201.09 & 91.81 & 514.8 & $1: 2: 5$ \\
\hline
\end{tabular}

Certainly, the increase of $\mathrm{Ca}$ and $\mathrm{Mg}$ is due to the solubilization of the limestone rocks that reacted with the vinasse that has an acidic $\mathrm{pH}$.

The $\mathrm{K}$ decrease is probably due the reaction of this element with the soluble materials inside the reactor. For instance, the water used in the dilution of the vinasse was from the water supply of the city with chlorine added. The chlorine could have reacted with the potassium, forming potassium chloride, what reduces the levels of this element in the ionic form, which would not be detected in the method used to quantify it.

The biogas was variable with the application of $3.0 \mathrm{~g} \mathrm{COD} \mathrm{L}^{-1}$ and $5.0 \mathrm{~g} \mathrm{COD} \mathrm{L}^{-1}$, respectively. In the other phases the biogas was not measured.

The biogas production was near $0.50 \mathrm{~L} / \mathrm{d}$ (standard coefficient $\pm 0.27 \mathrm{~L} / \mathrm{d}$ ) in the standard conditions, normal temperature and pressure (NTP), and the maximum value achieved was $1.37 \mathrm{~L}^{-1} \mathrm{~d}^{-1}$ with $3.0 \mathrm{~g} \mathrm{COD} \mathrm{L}^{-1}$. It is estimated that the conversion to biogas $\left(\mathrm{CH}_{4}\right.$ and $\left.\mathrm{CO}_{2}\right)$ was $47 \%$ and $30 \%$ to methane (considering that the biogas was about $65 \% \mathrm{CH}_{4}$ ).

Theoretically, if all organic matter applied is anaerobically biodegraded and converted to methane, then $0.35 \mathrm{~L}$ methane per $\mathrm{g}$ COD added in the standard conditions are expected to be converted. Then, with $5.0 \mathrm{~g} \mathrm{COD} \mathrm{L}{ }^{-1}$, the biogas was on average $0.38 \pm 0.18 \mathrm{~L}^{-\mathrm{d}^{-1}}$ (NTP), $0.21 \mathrm{~L}$ methane per day and the conversion to biogas $\left(\mathrm{CH}_{4}\right.$ and $\left.\mathrm{CO}_{2}\right)$ was $22 \%$ and $12 \%$ to COD: $\mathrm{CH}_{4}$.

Therefore, in these two phases where the biogas results were analyzed, it was possible to suppose that the average biogas production during the experimental period could be under the maximum in the conversion of organic matter in biogas or methane.

The wear on the limestone was determined at the end of the experimental period by determining the difference in volume. It was determined that $1.3 \mathrm{~L}$ of dolomitic limestone (2.87 $\mathrm{g} \mathrm{cm}^{-3}$, regarding Sampaio and Almeida, 2008) was eroded during the 129 days of the experiment. It is estimated that one kilogram of calcareous limestone is needed to treat 89 liters 
of vinasse in the evaluated concentrations. This amount shows the applicability of limestone's use in wastewater anaerobic treatment.

According to the results obtained, the reactor treatment system filled with dolomitic limestone is promising. However, the conditions of organic loading and phase separation are not conclusive.

Phase separation is economically feasible when scaling up anaerobic digestion plants in biorefineries. Despite the higher capital and operating costs in such schemes, the estimated biogas and electricity production costs reached equivalent or lower values compared with those of single-phase anaerobic digestion layouts (Fuess et al., 2017).

Finally, the use of limestone in this single reactor was an interesting $\mathrm{pH}$ conditioner and balancer of macro elements ( $\mathrm{Ca}, \mathrm{Mg}$ and $\mathrm{K})$.

\section{CONCLUSION}

The results obtained in this research demonstrated that the proposed system in a single physical compartment reduced organic matter and potassium, which are the largest inconveniences of the vinasse when disposed in soil without treatment.

Despite the difficult adaptation of the reactor to higher organic loads and instability with 3.0 to $12.0 \mathrm{~g} \mathrm{COD} \mathrm{L}^{-1}$, effluent anaerobically treated by the reactor filled with limestone presented an increase in levels of calcium, magnesium, $\mathrm{pH}$ and alkalinity to $71 \%, 74 \%$, $6.3,2048 \mathrm{mgCaCO}_{3} \mathrm{~L}^{-1}$ in the intermediate organic load of $7.5 \mathrm{~g} \mathrm{COD} \mathrm{L}^{-1}$, respectively. Also, the treated wastewater can benefit soil, and may motivate the use of this type of reactor to be placed in channels through which the vinasse flows until it reaches crops, thus eliminating the need for a larger area for this purpose.

More studies are necessary to achieve greater COD removal efficiency and conversion to methane. The same system in two physical phases (acidogenic and methanogen) and other support materials inside the reactors to adhere to biomass should be evaluated.

\section{ACKNOWLEDGMENTS}

The authors acknowledge to International Foundation for Science (IFS) for the financial support (project W/4391-1) and to USACIGA Plant for the cane vinasse donation.

\section{REFERENCES}

AGÊNCIA NACIONAL DO PETRÓLEO, GÁS NATURAL E BIOCOMBUSTÍVEIS - ANP. Boletim Gerencial: Superintendência de Abastecimento. Abastecimento em números, V. 11, n. 53, 2016.

AMERICAN PUBLIC HEALTH ASSOCIATION - APHA. Standard methods for the examination of water and wastewater. 22th ed. Washington, D.C, 2012.

AMERICAN SOCIETY FOR TESTING AND MATERIAL - ASTM. Standard Specification for Concrete Aggregates. International C33M-16e1. West Conshohocken, 2016.

AQUINO, S.; FUESS, L.T.; PIRES, E. C. Media arrangement impacts cell growth in anaerobic fixed-bed reactors treating sugarcane vinasse: Structured vs. randomic biomass immobilization, Bioresource Technology, v. 235, p. 219-228, 2017. https://doi.org/10.1016/j.biortech.2017.03.120

BALAGUER, M. D.; VICENT, M. T.; PARIS, J. M. A comparison of different support materials in anaerobic fluidized bed reactors for the treatment of vinasse. Environmental Technology, v. 18, p. 539-544, 1997. http://dx.doi.org/10.1080/09593331808616570 
BATAGLIA, O. C.; CAMARGO, O. A.; BERTON, R. S. Emprego da vinhaça na cultura de citros. Laranja, v. 7, p. 277-289, 1986.

BRAZIL. Ministério da Agricultura, Pecuária e Abastecimento. Produção brasileira de canade-açúcar, açúcar e etanol. 02 fev. 2017. Available in: http://www.agricultura.gov.br/assuntos/sustentabilidade/agroenergia/producao. Access in: 13 June 2017.

CHRISTOFOLETTI, C. A.; ESCHER, J. P.; CORREIA, J. E.; MARINHO, J. F. U.; FONTANETTI, C. S. Sugarcane vinasse: Environmental implications of its use. Waste $\begin{array}{lllllll}\text { Management, } & \text { v. } & 33, & \text { n. } & 12, & \text { p. }\end{array}$ https://doi.org/10.1016/j.wasman.2013.09.005

CONSELHO NACIONAL DO MEIO AMBIENTE - CONAMA. Resolução n. 357, de 17 de março de 2005. Dispõe sobre a classificação dos corpos de água e diretrizes ambientais para o seu enquadramento, bem como estabelece as condições e padrões de lançamento de efluentes, e dá outras providências. Diário Oficial [da] União, Brasília, 18 Mar. 2005.

DILALLO, R.; ALBERTSON, O. E. Volatile acids by direct titration. Journal Of Water Pollution Control Federation, v. 33, n. 4, p. 356-356, 1961. https://doi.org/10.1016/j.wasman.2013.09.005

DRIESSEN, W. J. B. M.; TIELBAARD, M. H.; VEREIJKEN, T. L. F. M. Experience on anaerobic treatment of distillery effluent with the UASB process. Water Science Technology, v. 30, n. 12, p. 193-201, 1994.

FDZ-POLANCO, F.; FDZ-POLANCO, M.; FERNANDEZ, N.; URUEÑA, M. A.; GARCIA, P. A.; VILLAVERDE, S. Simultaneous organic nitrogen and sulfate removal in an anaerobic GAC fluidized bed reactor. Water Science and Technology, v. 44, n. 4, p. 15$22,2001$.

FERRAZ JÚNIOR, A. D. N.; KOYAMA, M. H.; ARAÚJO JÚNIOR, M. M.; ZAIAT, M. Thermophilic anaerobic digestion of raw sugarcane vinasse, Renewable Energy, v. 89, p. 245-252, 2016. http://dx.doi.org/10.1016/j.renene.2015.11.064

FORESTI, E. Foundations of the process of anaerobic digestion. In: TALLER OF ANAEROBIC DIGESTION, 3., 1994, Montevideo. Proceedings... Montevideo, 1994. p. 97-110.

FUESS, L. T.; ARAÚJO JÚNIOR, M. M.; GARCIA, M. L.; ZAIAT, M. Designing full- scale biodigestion plants for the treatment of vinasse in sugarcane biorefineries: How phase separation and alkalinization impact biogas and electricity production costs?, Chemical Engineering Research and Design, v. 119, p. 209-220, 2017. https://doi.org/10.1016/j.cherd.2017.01.023

GUAGNONI, W. C.; NAKAO, S. H.; RIBEIRO, M. S. Decisions of Investment and Environment in the Setor Sucroalcooleiro. In: INTERNATIONAL CONFERENCE OF THE IBEROAMERICAM ACADEMY OF MANAGEMENT, 3., 2003, São Paulo. Proceedings... São 2003. Paulo. Available in: http://www.fgvsp.br/iberoamerican/Papers/0341_Artigo-decisoes-investimentoambiental-06.pdf. Access in: 17 July 2007.

HARADA, H.; UEMURA, S.; CHEN, A. C.; JAYADEVAN, J. Anaerobic treatment of recalcitrant distillery wastewater by a thermophilic UASB reactor. Bioresource Technology, v. 55, p. 215 - 221, 1996. https://doi.org/10.1016/0960-8524(96)00003-X 
KUBIAK, C.; DUBUIS, T. Valorization of the objects and of the efluentes agricultural, industrial and domestic. In: SCRIBAN, R.; ARNAUD, A.; PEREIRA, M. E. G. G. Biotechnology. São Paulo: Manole, 1985. p. 401-421.

MORAES, B. S.; ZAIAT, M.; BONOMI, A. Anaerobic digestion of vinasse from sugarcane ethanol production in Brazil: Challenges and perspectives. Renewable and Sustainable Energy Reviews, v. 44, p. 888-903, 2015. http://dx.doi.org/10.1016/j.rser.2015.01.023

MOSEY, F. New developments in the anaerobic treatment of industrial wastes. Water Pollution Control, v. 81, p. 540-52, 1982.

POHLAND, F. G.; GHOSH, S. Development in anaerobic stabilization of organic wastes - The two-phase concept. Environmental Letters, v. 1, n. 4, p. 255, 1971. http://dx.doi.org/10.1080/00139307109434990

RIBAS, M. M. F. Tratamento de vinhaça em reator anaeróbio operado em batelada seqüencial contendo biomassa imobilizada sob condições termofílicas e mesofílicas. 2006. Tese (Doutorado em Hidráulica e Saneamento) - Escola de Engenharia de São Carlos, Universidade de São Paulo, São Carlos, 2006. http://dx.doi/org/10.11606/T.18.2006.tde-19032007-171353

RIBAS, M. M. F.; BARANA, A. C. Start-up adjustment of a plug-flow digester for cassava wastewater (manipueira) treatment. Scientia Agricola, v. 60, n. 2, p. 223-229, 2003.

RIBAS, M. M. F.; CEREDA, M. P. Stabilization of cassava wastewater during acidogenic phase in anaerobic reactor with sodium hydroxide $(\mathrm{NaOH})$ and two sizes of dolomitic limestone. Journal of Root Crops, v. 29, n. 2, p. 4-9, 2003. http://dx.doi.org/10.1590/S0103-90162003000200004

RIPLEY, L. E.; BOYLE, W. C.; CONVERSE, J. C. Improved alkalimetric monitoring anaerobic digestion of high-strength wastes. Journal of Water Pollution Control Federation, v. 58, p. 406-411, 1986. http://www.jstor.org/stable/25042933

SAMPAIO, J. A.; ALMEIDA, S. L. M. Calcário e dolomito. In: CETEM. Rochas e minerais industriais. 2. ed. Rio de Janeiro: CETEM, 2008. p. 363-391.

SPEECE, R. E. Anaerobic biotechnology is industrial wastewater treatment. Nashville: Archae Press, 1996. 394p.

SILVA, M. A. S.; GRIEBELER, N. P.; BORGES, L. C. Uso de vinhaça e impactos nas propriedades do solo e lençol freático. Revista Brasileira de Engenharia Agrícola e $\begin{array}{llllll}\text { Ambiental, } & \text { v. } & 11, & \text { n. } & 1, & \text { p.108-114, }\end{array}$ https://doi.org/10.1590/S1415-43662007000100001

SILVA, R. A. P.; BONCZ, M. A. Aplicação do calcário no tamponamento da acidez em processos de digestão anaeróbia: análise inicial. 2012. 11p. Trabalho de Conclusão de Curso (Graduação) - Campus do Pantanal, Universidade Federal de Mato Grosso do Sul, 2012.

SILVA, A. M.; LIMA, R. M. F.; LEÃO, V. A. Mine water treatment with limestone for sulfate removal. Journal of Hazardous Materials, v. 221-222, p. 45-55, 2012. https://doi.org/10.1016/j.jhazmat.2012.03.066

SOUZA, M. E.; FUZARO, G.; POLEGATO, A. R. Thermophilic anaerobic digestion of vinasse in pilot plant uasb reactor. Water Science Technology, v. 25, n. 7, p. 213-222, 1992. 
TEHL, M. Avaliação do uso de reator anaeróbio horizontal de leito fixo no tratamento da vinhaça sob condições termofílicas. 2001. 60 p. Dissertação (Mestrado) - Escola de Engenharia de São Carlos, Universidade de São Paulo, 2001

TONELLO, A. P.; RIBAS, M. M. F. Desempenho de reatores anaeróbios horizontais de leito fixo e fases separadas tratando vinhaça. OLAM - Ciência and Tecnologia, n. 2, p. 345$361,2009$.

VIANA, A. B. Tratamento anaeróbio de vinhaça em reator UASB operado em temperatura na faixa termofílica $\left(5^{\circ} \mathrm{C}\right)$ e submetido ao aumento progressivo de carga orgânica. 2006. Dissertação (Mestrado em Hidráulica e Saneamento) - Escola de Engenharia de São Carlos, Universidade de São Paulo, São Paulo, 2006. http://dx.doi.org/10.11606/D.18.2006.tde-26032007-125625

VLISSIDIS, A.; ZOUBOULIS, A. I. Thermophilic anaerobic digestion of alcohol distillery wastewaters. Bioresource Technology, v. 43, p. 131-140, 1993. https://doi.org/10.1016/0960-8524(93)90172-8

WATTEN, B. J.; MUDRAK, V. A.; ECHEVARRIA, C.; SIBRELL, P. L.; SUMMERFELT, S. T.; BOYD, C. E. Performance and application of a fluidized bed limestone reactor designed for control of alkalinity, hardness and $\mathrm{pH}$ at the Warm Springs Regional Fisheries Center, Aquacultural Engineering, v. 77, p. 97-106, 2017, https://doi.org/10.1016/j.aquaeng.2017.03.003

WIEGANT, W. M.; CLAASSEN, J. A.; LETTINGA, G. Thermophilic anaerobic digestion of high strength wastewaters. Biotechonology and Bioengineering, v. 37, p. 1374-1381, 1986. http://dx.doi.org/10.1002/bit.260270915

WILKIE, A. C.; RIEDESEL, K. J.; OWENS, J. M. Stillage characterization and anaerobic treatment of ethanol stillage from conventional and cellulosic feedstocks. Biomass and Bioenergy, v. 19, p. 63 - 102, 2000. https://doi.org/10.1016/S0961-9534(00)00017-9

ZHOU, W.; SUN, Y.; WU, B.; ZHANG, Y.; ZHANG, Z. Autotrophic denitrification for nitrate and nitrite removal using sulfur-limestone. Journal of Environmental Sciences, v. 23, n. 11, p. 1761-1769, 2011. https://doi.org/10.1016/S1001-0742(10)60635-3 